\title{
Evaluation of Corpus Callosum Morphometry in Pediatric Population, is there any Difference Between Genders?
}

\author{
Pediatrik Popülasyonda Korpus Kallozum Morfometrisinin \\ Değerlendirilmesi, Cinsiyetler Arasında Fark Var Mı?
}

\author{
DOlga Bayar Kapici, @Ali Haydar Baykan \\ Adıyaman Training and Research Hospital, Radiology Department, Adıyaman, Turkey \\ Copyright@Author(s) - Available online at www.dergipark.org.tr/tr/pub/medr \\ Content of this journal is licensed under a Creative Commons Attribution-NonCommercial 4.0 International License.
}

\begin{abstract}
Aim: Corpus callosum (CC) is a white matter structure and it is the largest interhemispheric commissure that connects the brain hemispheres. The morphology of CC can be affected by congenital and acquired diseases, sex, age, and hand selection. This study aims to investigate morphometric features of $\mathrm{CC}$ by age and gender.

Material and Methods: Thickness of all corpus callosum segments and length of the long axis of the CC of the healthy pediatric population were measured via magnetic resonance imaging (MRI) from the midsagittal line where the septum pellucidum and massa intermedia can be monitored. A total of 240 participants (120 males and 120 females) were divided into four age groups; 0-2 age group, 3-6 age group, 7-11 age group, and 12-17 age group and thickness of the five segments of the CC (rostrum, genu, body, isthmus, splenium) and anterior-posterior length of the CC were measured.

Results: Thicknesses of four segments that included genu, body, isthmus, and splenium (except the rostrum) and length of the long axis of CC increased significantly with age in both genders. However, when we evaluated all participants without gender discrimination, the thickness of all segments of CC and length of the long axis are observed to increase significantly.

Conclusion: The obtained data from the healthy pediatric population will help differentiate the abnormal morphometric changes of $\mathrm{CC}$ due to congenital and acquired diseases.

Keywords: Corpus callosum; magnetic resonance imaging; pediatric population

$\mathrm{Oz}$

Amaç: Korpus kallozum (CC) bir beyaz cevher yapısıdır ve beyin hemisferlerini birbirine bağlayan en büyük interhemisferik komissürdür. CC'nin morfolojisi doğuştan ve edinilmiş hastalıklardan, cinsiyetten, yaştan ve el seçiminden etkilenebilir. Bu çalışma CC'nin morfometrik özelliklerini yaşa ve cinsiyete göre incelemeyi amaçlamaktadır.

Materyal ve Metot: Sağlıklı pediatrik popülasyonun tüm korpus kallozum segmentlerinin kalınlığı ve CC'nin uzun ekseninin uzunluğu, septum pellusidum ve massa intermedia'nın izlenebildiği midsagittal hattan manyetik rezonans görüntüleme (MRI) ile ölçüldü. Toplam 240 katılımcı (120 erkek ve 120 kadın) dört yaş grubuna ayrıldı; 0-2 yaş grubu, 3-6 yaş grubu, 7-11 yaş grubu ve 12-17 yaş grubu ve CC'nin beş segmentinin kalınlığı (rostrum, genu, gövde, isthmus, splenium) ve CC'nin anterior-posterior uzunluğu ölçüldü. Bulgular: Her iki cinsiyette de CC'nin uzun ekseninin uzunluğu ve CC segmentlerinin kalınlığı (rostrum hariç) yaşla birlikte anlamlı olarak artmaktaydı. Ancak cinsiyet ayrımı yapmadan tüm katılımcıları değerlendirdiğimizde CC'nin tüm segmentlerinin kalınlığının ve uzun eksen uzunluğunun yaşla birlikte istatistiksel olarak anlamlı şekilde arttığı görülmektedir.

Sonuç: Sağlıklı pediatrik popülasyondan elde edilen veriler, doğumsal ve edinsel hastalıklara bağlı olarak CC'nin anormal morfometrik değişikliklerini ayırt etmeye yardımcı olacaktır.
\end{abstract}

Anahtar Kelimeler. Korpus kallozum; manyetik rezonans görüntüleme; pediatrik popülasyon

Geliş Tarihi / Received: 02.02.2021 Kabul Tarihi / Accepted: 30.03.2021

Sorumlu Yazar /Corresponding Author. Olga Bayar Kapici, Adıyaman Training and Research Hospital, Radiology

Department, Adıyaman, Turkey, E-mail: olgasahbayar@gmail.com 


\section{INTRODUCTION}

Corpus callosum (CC) is a crescent-shaped white matter structureextending fromanteriorto posterior, approximately $10 \mathrm{~cm}$ long, located deep in the interhemispheric fissure (1). Based on the former histological findings, CC consists of four sections: rostrum, genu, body, splenium. These structures connect different areas of the cortex (2). The rostrum and the genu in the anterior region of CC provide the connections between the anterior regions of the frontal lobes and form forceps minor (3). The body in the middle section of CC provides the connections between the precentral and premotor region of the frontal lobe and the parietal lobe and temporal lobe.

Splenium in the posterior section of CC is essential in the formation of forceps major, which connects with the occipitotemporal region (4). Isthmus is named for the narrowest region between the body and the splenium part of CC (5).

Although all callosal fibers are present at birth in healthy people, myelination in these fibers continues from postnatal fourth month to young adulthood (6). It has been proved that the weakened integrity of $\mathrm{CC}$ with aging causes a decrease in cognitive functions, and increased callosal thickness in children is associated with higher intelligence, problem-solving, and processing skills (7).

Thinning of CC may be focal or diffuse depending on primary and secondary reasons. Primary causes are factors affecting myelination such as leukoencephalopathy, myelination disorder, metabolic diseases affecting white matter. Secondary causes are myelin damages such as hypoxic-ischemic encephalopathy, diffuse axonal damage secondary to trauma, and hydrocephalus (8).

The corpus callosum agenesis (CCA) occurs with the deterioration of callosal development due to the delay in developing the posterior and anterior parts of CC. Partial CCA occurs in the later stages of development, especially with disruptions in the development of the rostrum and the posterior part of CC (9).

Radiological evaluation of CC can be done using magnetic resonance imaging (MRI), computed tomography (CT), diffusion tensor imaging (DTI), transfontanelle ultrasonography (US), obstetric US, transvaginal US, and fetal MRI (10).

Imaging findings may vary depending on the degree of corpus callosum dysgenesis (CCD). Enlargement of the posterior horns of the lateral ventricle and colpocephaly are observed in the absence of splenium. In CCA, a wide high-placement third ventricle is seen with colpocephaly. In addition, other accompanying anomalies can be detected with CCA / CCD (11).

In this study, we aimed to evaluate morphometric differences between genders and age groups in a healthy pediatric population using quantitative analysis of CC.

\section{MATERIAL AND METHODS}

In the present study, the data retrospectively obtained from the Radiology Department of Adıyaman University Training and Research Hospital archives were used.

The study was approved by the ocal ethics committee (approval number: 2019/3-23). All procedures performed in studies involving human participants were in accordance with the ethical standards of the institutional research committee and with the 1964 Helsinki declaration and its later amendments or comparable ethical standards.

Two hundred forty participants (120 males and 120 females) who had undergone non-contrast brain MRI between January 2017 and March 2019 are included in the study. Brain MRI, clinical examinations and follow-up of these participants were evaluated as normal.

The participants have divided into four age groups as 0-2 years, 3-6 years, $7-11$ years, and 12-17 years. Each group included 30 males and 30 females participants. With the information obtained from the archive research, cases with a congenital or acquired disease and low MR image quality were excluded.

\section{MRI protocol and imaging analysis}

In all cases, the MRI examination was obtained from the Philips Achieva MR device (Philips Medical Systems, Best, Netherlands) with a 1.5 Tesla magnetic field strength using a head coil. The section from T1 FLAIR-weighted images through the cranial midline where the massa intermedia can be seen at the sagittal plane was selected for examination. [time to repeat (TR): $1665 \mathrm{~ms}$, time to echo (TE): $20 \mathrm{~ms}$, FOV: 220x230, slice thickness: $5 \mathrm{~mm}$, matrix: 292x214, NSA: 1, gap :1 mm, voxel: $0.75 \times 1.07 \times 5$, slices : 24 sections]

Images were evaluated at Philips Achieva Rev R5 v30rev.02 workstation and our hospital's PACS system and measurements were made in $\mathrm{mm}$.

On MRI, CC measurements were made from 5 segments as rostrum, genu, body, isthmus, and splenium. Witelson lines were used when measuring genu and rostrum thicknesses (10). The illustration showing the Witelson lines is shown in figure 1.

It was shown as the craniocaudal virtual line $(\ell 1)$, tangent through CC's anterior inner convex, and this line separated the genu and the rostrum. The rostrum is a triangular structure and is shown as a perpendicular line ( $(2)$ drawn from the inferior anterior corner of the rostrum to the superomedial base. The rostrum thickness was measured with this virtual line drawn. (Figure 2)

The anterior-posterior diameter (AP diameter) of CC was measured as the length of the line drawn between the extreme anterior point of the genu and the extreme posterior point of the splenium. (Figure 3) 


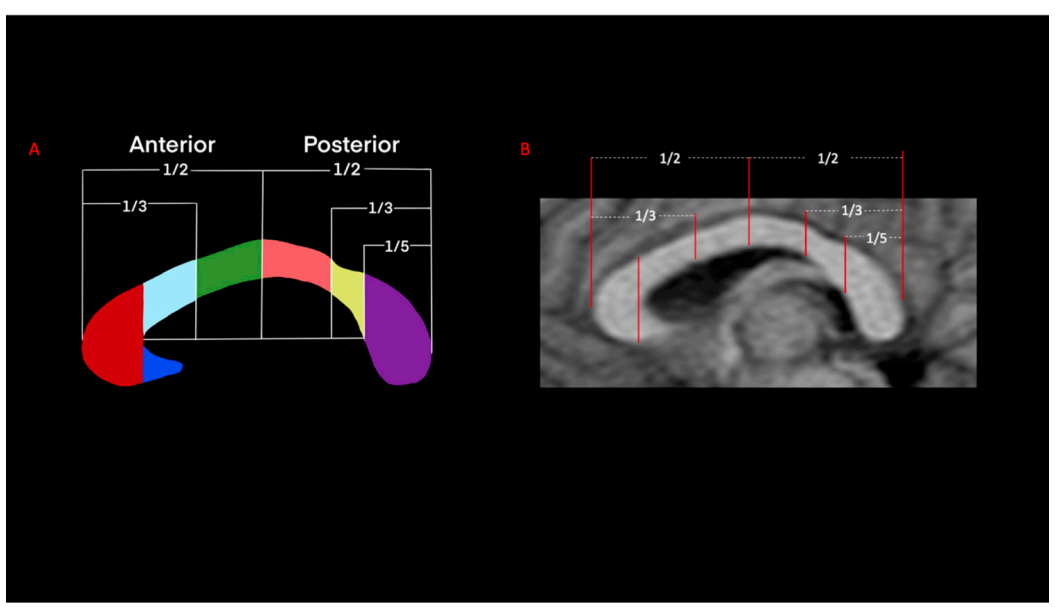

Figure 1. Illustration (A) and T1 FLAIR sequence on MRI (B) showing the separation of corpus callosum into segments with Witelson lines.

Notes: Blue color: rostrum, red color: genu, light blue color: rostral body, green color: anterior middle body, pink color: posterior middle body, yellow color: isthmus, purple color: splenium

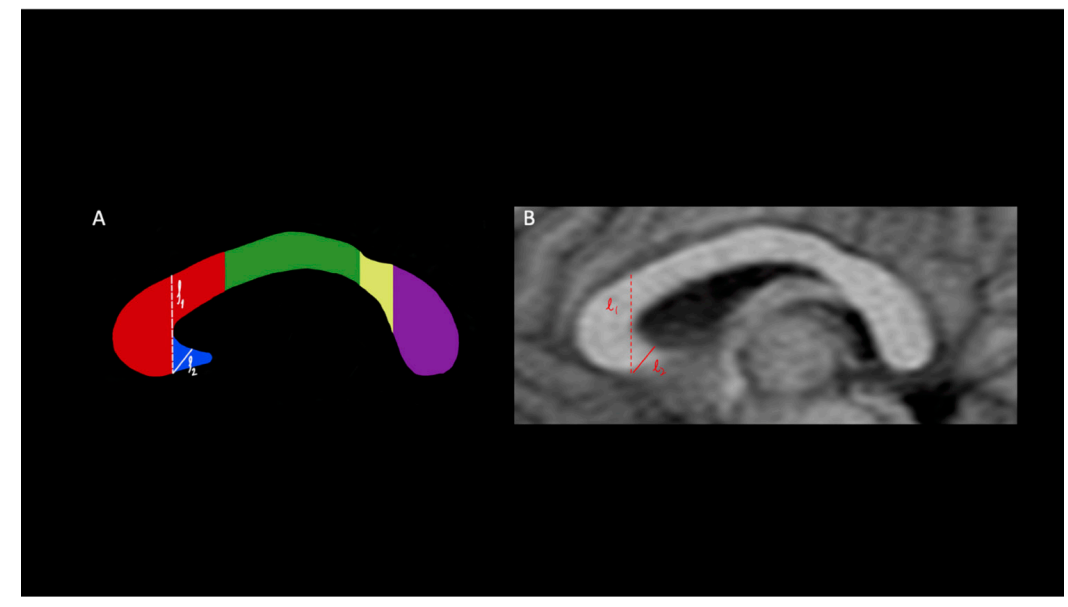

Figure 2. Ilustration (A) and T1 FLAIR sequence on MRI (B) showing the Virtual Line ( $(1)$ that Separates Rostrum and Genu from

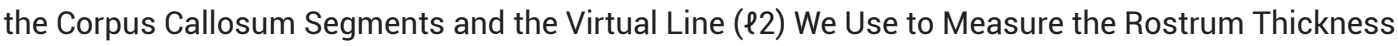

Notes: Blue color: rostrum, red color: genu, green color: body, yellow color: isthmus, purple color: splenium

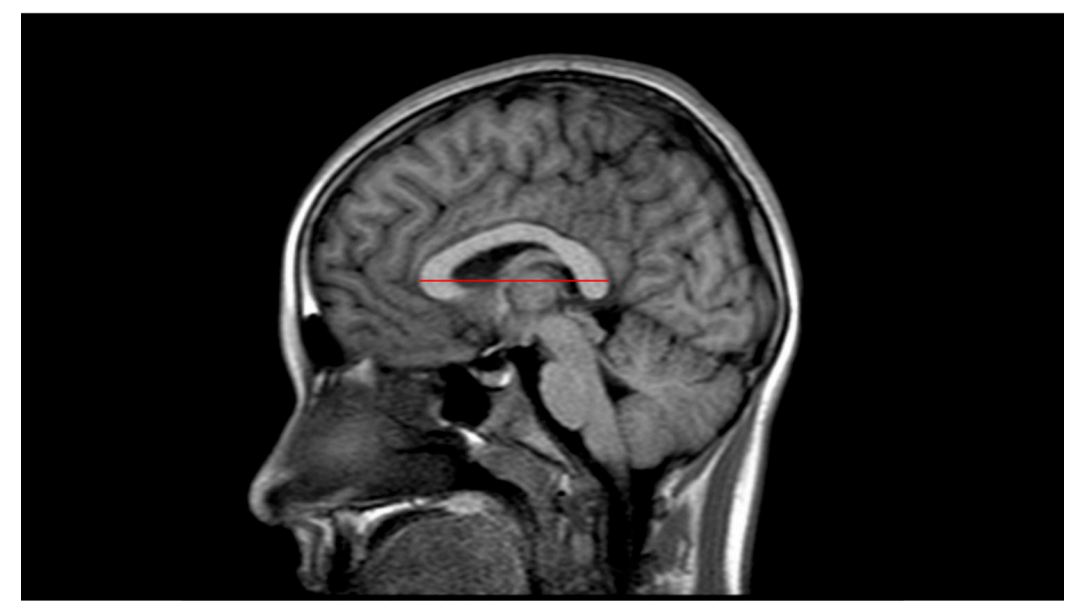

Figure 3. Measurement of the Anterior - Posterior Length of Corpus Callosum in the Midsagital Section in The T1 FLAIR Sequence on MRI 


\section{Statistical analysis}

The suitability of the data to normal distribution was evaluated with one sample Kolmogorov Smirnov (KS) test. According to the results of the KS test, all data showed normal distribution. One-way analysis of variance (ANOVA) and posthoc Tukey HSD were used to determine the difference between age groups. Independent sample $\mathrm{t}$-tests were used to determine gender difference. Results are given as mean and standard deviation. The level of significance was accepted $\mathrm{p}<0.05$ for all analyses. All analyzes were performed using the software package program SPSS / PC (Version 22.0 SPSS, Chicago, II, USA)

\section{RESULTS}

There are four different age groups in our study, and the same genders were compared between the age groups and the participants in the same age group were compared between genders. Besides, all participants were compared among themselves by age groups without gender discrimination.

The comparison of CC segment thicknesses between age groups and genders is shown in Table 1.

Except for the rostrum, all segment thicknesses increased significantly with increasing age in both genders.

When the male and female participants in the same age groups were compared, genu thickness was significantly smaller in females in the 7-11 age group than those males $(p<0.05)$. Isthmus thickness was significantly smaller in female cases in the $0-2$ age group than those males $(p<0.05)$.

The comparison of CC AP length between age groups and genders is shown in Table 2 . In both genders, this value increased significantly in higher age groups $(p<0.05)$.

The CC AP value was significantly lower in the $0-2$ age group than other age groups for the female participants $(p<0,05)$, while the value of the $12-17$ age group was significantly higher than other age groups $(p<0.05)$. CC AP value was significantly smaller in the $0-2$ age group than other age groups for the male participants $(p<0.05)$.

Comparison of data in all participants by age groups without gender discrimination is summarized in Table 3 . According to this table, all values significantly increased with higher age groups $(p<0.05)$. When age groups compared the values, there was a significant difference between the 0-2 age group and the 3-6 age group in terms of rostrum thickness $(p<0.05)$, but there was no significant difference between other age groups. Genu thickness was significantly different in each age group $(p<0.05)$.

The thickness of body, isthmus, and splenium segments were significantly smaller in the $0-2$ age group than other age groups $(p<0.05)$. Splenium thickness was significantly larger in the $12-17$ age group $(p<0.05)$. CC AP showed a significant difference in each age group ( $p$ $<0.05)$.

\section{DISCUSSION}

Since CC is a white matter structure composed of myelinated nerve fibers, its development from the fetal period to the adult period has always been a matter of curiosity. There are studies in the literature regarding the development of CC in childhood, the relationship of CC with the development of cognitive functions in adolescence, the relationship of $\mathrm{CC}$ anomalies with neuropsychiatric diseases and the differences of CC between genders (6, 12-15). The first study on the development and gender differences of CC was published in 1982 by DeLacoste et al. (16) and they found the splenium thickness larger in females. However, in many subsequent studies $(12,17,18)$, there was no significant difference between genders in CC morphometry.

In the present study, we aimed to determine the average morphological values of the $\mathrm{CC}$ by measuring the segment thicknesses and length of the long axis of the CC in the pediatric population. We believe that it will be proper to determine the expected values of the CC's morphometric measures. Developmental anomalies, myelination disorders, and pathological conditions such as loss of axons due to degeneration, ischemia, or trauma may affect CC morphology. Also, demographic differences such as gender, age, and right or left hand may alter CC morphometry. These situations may affect diffuse or focally the morphological structure of CC $(16,19)$.

When we examine the studies on the Turkish population in the literature, studies were comparing CC segment thickness and CC long axis length between age groups and genders in healthy adults and changes in CC with aging (20-22). Although studies regarding CC's morphometry in the Turkish literature mostly focused on the adult population, there is a study conducted by Akin et al (23) in the pediatric population. Akin et al. conducted their research on 200 children at $6-18$ age group and they found no difference between genders. In the literature, we did not find any study on the development process of CC in the healthy pediatric population, including the infancy period in the Turkish population.

Giedd et al. (12) found that the anterior segments (rostrum and genu) of CC reached adult measurements in the preschool period by comparing the child and adult groups. However, they found that CC's posterior and middle segments were significantly smaller in the children group than the adult group. We believe that the rostrum completed its development early because we could not find a significant difference in terms of rostrum thickness between age groups in both genders. Unlike their results, we found that the development of the genu continues in the adolescent period in females. Giedd et al. did not find a significant difference when they compared genders in their study. In the present study, we found that the thickness of genu was significantly larger in male school-age participants (7-11 age) than those female participants. Additionally, our results have shown that isthmus thickness was larger in males in the infant 
Table 1. Statistical analysis of thickness data of corpus callosum segments between age groups and genders

\begin{tabular}{|c|c|c|c|c|c|c|}
\hline & & $\begin{array}{c}0-2 \\
\text { Age Group }\end{array}$ & $\begin{array}{c}3-6 \\
\text { Age Group }\end{array}$ & $\begin{array}{c}7-11 \\
\text { Age Group }\end{array}$ & $\begin{array}{c}12-17 \\
\text { Age Group }\end{array}$ & $P *$ value \\
\hline \multirow{3}{*}{ Rostrum } & Female $(n=30)$ & $4.18 \pm 0.66$ & $4.5 \pm 1.01$ & $4.41 \pm 0.96$ & $4.6 \pm 0.9$ & 0.089 \\
\hline & Male $(n=30)$ & $4.46 \pm 1.01$ & $5.003 \pm 1.24$ & $4.66 \pm 0.82$ & $4.71 \pm 0.87$ & 0.219 \\
\hline & $P * *$ value & 0.224 & 0.391 & 0.287 & 0.643 & \\
\hline \multirow{3}{*}{ Genu } & Female $(n=30)$ & $7.84 \pm 1.13 a$ & $9.02 \pm 1.33 b$ & $9.41 \pm 1.45 b$ & $10.86 \pm 1.33 c$ & $<0.001$ \\
\hline & Male $(n=30)$ & $8.12 \pm 1.46 a$ & $9.44 \pm 1.34 b$ & $10.58 \pm 1.35 c$ & $10.87 \pm 1.3 c$ & $<0.001$ \\
\hline & $\mathrm{P} * \star$ value & 0.423 & 0.229 & $0.002 *$ & 0.977 & \\
\hline \multirow{3}{*}{ Body } & Female $(n=30)$ & $4.21 \pm 0.8 \mathrm{a}$ & $5.31 \pm 1.07 b$ & $5.38 \pm 0.91 b$ & $5.86 \pm 0.65 b$ & $<0.001$ \\
\hline & Male $(n=30)$ & $4.53 \pm 1.01 a$ & $5.34 \pm 1.005 b$ & $5.5 \pm 1.08 \mathrm{~b}$ & $5.69 \pm 0.54 b$ & $<0.001$ \\
\hline & $P * *$ value & 0.185 & 0.912 & 0.644 & 0.27 & \\
\hline \multirow{3}{*}{ Isthmus } & Female $(n=30)$ & $2.39 \pm 0.72 a$ & $3.37 \pm 0.71 b$ & $3.31 \pm 0.96 b$ & $3.48 \pm 0.79 b$ & $<0.001$ \\
\hline & Male $(n=30)$ & $2.74 \pm 0.64 a$ & $3.29 \pm 0.86 b$ & $3.57 \pm 0.74 b$ & $3.45 \pm 0.83 b$ & $<0.001$ \\
\hline & $P * \star$ value & 0.049 * & 0.686 & 0.245 & 0.875 & \\
\hline \multirow{3}{*}{ Splenium } & Female $(n=30)$ & $7.28 \pm 1.16 a$ & $8.11 \pm 1.3 \mathrm{ab}$ & $8.6 \pm 1.44 b$ & $10.08 \pm 1.1 \mathrm{c}$ & $<0.001$ \\
\hline & Male $(n=30)$ & $7.42 \pm 1.34 a$ & $8.55 \pm 0.96 b$ & $8.85 \pm 1.3 b c$ & $9.66 \pm 1.42 c$ & $<0.001$ \\
\hline & & 0.661 & 0.148 & 0.478 & 0.201 & \\
\hline
\end{tabular}

abcd: Different letters in the same line show statistically significant difference $(p<0.05)$ Mean \pm standard deviation was used. Tukey HSD multiple comparison test was used. *: Indicates one-way analysis of variance. **: Two independent samples show t test results.

Table 2. Statistical analysis of corpus callosum anterior-posterior length between age groups and gender

\begin{tabular}{|c|c|c|c|c|c|c|}
\hline & & $\begin{array}{c}0-2 \\
\text { Age Group }\end{array}$ & $\begin{array}{c}3-6 \\
\text { Age Group }\end{array}$ & $\begin{array}{c}\text { 7-11 } \\
\text { Age Group }\end{array}$ & $\begin{array}{c}12-17 \\
\text { Age Group }\end{array}$ & $P$ * value \\
\hline \multirow{3}{*}{ CC AP } & Female $(n=30)$ & $56.8 \pm 3.76 a$ & $60.09 \pm 5.69 b$ & $63.2 \pm 5.1 b$ & $68.22 \pm 4.52 c$ & $<0.001$ \\
\hline & Male $(n=30)$ & $56.61 \pm 4.35 a$ & $60.88 \pm 3.91 b$ & $63.6 \pm 4.69 \mathrm{bc}$ & $66.13 \pm 5.07 \mathrm{c}$ & $<0.001$ \\
\hline & $P * *$ value & 0.857 & 0.53 & 0.74 & 0.098 & \\
\hline
\end{tabular}

abcd: Different letters in the same line show statistically significant difference $(p<0.05)$ Mean \pm standard deviation was used. Tukey HSD multiple comparison test was used. CC AP. Corpus callosum anterior-posteior length

*: One-way analysis of variance, ** Two independent samples show t test results.

Table 3. Statistical analysis of the data between age groups without gender discrimination

$\begin{array}{lccccc} & \begin{array}{c}0-2 \\ \text { Age Group } \\ (\mathrm{n}=60)\end{array} & \begin{array}{c}3-6 \\ \text { Age Group } \\ (\mathrm{n}=60)\end{array} & \begin{array}{c}7-11 \\ \text { Age Group } \\ (\mathrm{n}=60)\end{array} & \begin{array}{c}12-17 \\ \text { Age Group } \\ (\mathrm{n}=60)\end{array} & \begin{array}{c}\mathrm{P} \text { ( value } \\ 4.65 \pm 0.88 \mathrm{ab}\end{array} \\ \text { Rostrum } & 4.32 \pm 0.86 \mathrm{a} & 4.87 \pm 1.13 \mathrm{~b} & 4.53 \pm 0.9 \mathrm{ab} & 10.86 \pm 1.3 \mathrm{~d} & <.015 \\ \text { Genu } & 7.98 \pm 1.3 \mathrm{a} & 9.23 \pm 1.34 \mathrm{~b} & 9.99 \pm 1.51 \mathrm{c} & 5.78 \pm 0.6 \mathrm{c} & <0.001 \\ \text { Body } & 4.37 \pm 0.92 \mathrm{a} & 5.32 \pm 1.03 \mathrm{~b} & 5.44 \pm 0.99 \mathrm{bc} & 3.47 \pm 0.8 \mathrm{~b} & <0.001 \\ \text { Isthmus } & 2.56 \pm 0.7 \mathrm{a} & 3.33 \pm 0.78 \mathrm{~b} & 3.44 \pm 0.86 \mathrm{~b} & 8.87 \pm 1.28 \mathrm{c} \\ \text { Splenium } & 7.35 \pm 1.25 \mathrm{a} & 8.33 \pm 1.15 \mathrm{~b} & 8.72 \pm 1.36 \mathrm{~b} & 60.001 \\ \text { CC AP } & 56.71 \pm 4.03 \mathrm{a} & 60.48 \pm 4.86 \mathrm{~b} & 63.41 \pm 4.87 \mathrm{c} & 67.17 \pm 4.87 \mathrm{~d}\end{array}$

abcd: Different letters in the same line show statistically significant difference $(p<0.05)$ Mean \pm standard deviation was used. Tukey HSD multiple comparison test was used. CC AP. Corpus callosum anterior-posteior length. *: One way variance analysis 
period (0-2 age group) than those females.

Tanaka-Arakawa et al. (10) found that the thickness of all segments of CC (except rostral body) increased significantly with age. Unlike their results, we did not find a significant difference in rostrum thickness between age groups.

Guz et al. (15) found no difference between the genders in the $0-10$ age group in terms of CC long axis. However, they found that the CC long axis between the ages of 11-70 was more extensive in males, but this difference was not statistically significant. There was no significant difference between genders in terms of CC long axis in all age groups in the present study. Guz et al. stated that the thickness of the isthmus was more extensive in males in the 15-20 age group, but this difference was not statistically significant. However, we found that the isthmus thickness was significantly smaller in 0-2 year female participants than those male participants.

Achiron et al. (24) found the body segment thickness in female fetuses thicker than male fetuses. However, there is no significant difference between the genders in terms of body segment thickness, according to our results.

According to our data, for all participants, there was a significant increase in the rostrum's thickness as the age increased. When we examined the genders separately, there was no significant difference in the thickness of the rostrum between age groups. Further studies that include larger samples can help to understand the reasons for differences between genders and different age groups.

This study has some limitations. First of all, our study had a retrospective natüre, and all participants were considered healthy. Since this study was based only on the child population, no data on CC development in adulthood were found. In our study, isthmus thickness in the 0-2 age group and genu thickness in the 7-11 age group differ between genders.

To understand how different morphological structures of these segments affect a person cognitively and behaviorally, it may be necessary to follow the psychosomatic development of individuals until adulthood.

Our results have indicated that CC morphometries may vary at different age groups and between genders. These average morphometric values can compare and interpret abnormal CC structure changes due to congenital and acquired diseases.

Financial disclosures: All authors report no financial interests or potential conflicts of interest.

Conflict of Interest: The authors declare that they have no competing interest.

Ethical approval

Adıyaman University, (2019/3-23)

\section{REFERENCES}

1. Aralasmak A, Ulmer JL, Kocak M, et al. Association, commissural, and projection pathways and their functional deficit reported in literature. J Comput Assist Tomogr 2006;30:695-715.

2. Goldstein A, Covington BP, Mesfin FB. Neuroanatomy, Corpus Callosum. StatPearls [Internet]: StatPearls Publishing. 2019.

3. Tzourio-Mazoyer N. Intra- and Inter-hemispheric Connectivity Supporting Hemispheric Specialization. In: Kennedy H., Van Essen D., Christen Y. (eds) Micro-, Mesoand Macro-Connectomics of the Brain. Research and Perspectives in Neurosciences. Springer, Cham. 2016. p. 129-46.

4. Musiek FE. Neuroanatomy, neurophysiology, and central auditory assessment. Part III: Corpus callosum and efferent pathways. Ear Hear 1986;7:349-58.

5. Snell RS (2000) Clinical Neuroanatomy for Medical Students. George Washington University Washington-USA, Fourth Turkish Edition. Lıppıncott-Wılkıns / Nobel İstanbul, 2000; p. 265-70.

6. Gbedd JN, Blumenthal J, Jeffries NO et al. Development of the human corpus callosum during childhood and adolescence: a longitudinal MRI study. Prog Neuropsychopharmacol Biol Psychiatry 1999;23:571-88.

7. Hinkley LB, Marco EJ, Findlay AM et al. The role of corpus callosum development in functional connectivity and cognitive processing. PLoS One 2012;7:e39804.

8. Andronikou S, Pillay T, Gabuza L et al. Corpus callosum thickness in children: an MR pattern-recognition approach on the midsagittal image. Pediatr Radiol 2015;45:258-72.

9. Edwards TJ, Sherr EH, Barkovich AJ et al. Clinical, genetic and imaging findings identify new causes for corpus callosum development syndromes. Brain 2014;137:1579613.

10. Tanaka-Arakawa MM, Matsui M, Tanaka $C$ et al. Developmental changes in the corpus callosum from infancy to early adulthood: a structural magnetic resonance imaging study. PloS one 2015.10:e0118760.

11. Roy $E$, Hague $C$, Forster $B$ et al. The corpus callosum: imaging the middle of the road. Can Assoc Radiol J. 2014;65:141-7.

12. Giedd JN, Rumsey JM, Castellanos FX et al. A quantitative MRI study of the corpus callosum in children and adolescents. Dev Brain Res 1996;91:274-80.

13. Keshavan MS, Diwadkar VA, DeBellis M et al. Development of the corpus callosum in childhood, adolescence and early adulthood. Life sci 2002;70:1909-22.

14. Pujol J, Vendrell P, Junqué $C$ et al. When does human brain development end? Evidence of corpus callosum growth up to adulthood. Ann Neurol 1993;34:71-5.

15. Guz W, Pazdan D, Stachyra S et al. Analysis of corpus callosum size depending on age and sex. Folia morphol 2019;78:24-32.

16. DeLacoste-Utamsing C, Holloway RL. Sexual dimorphism in the human corpus callosum. Science 1982;216:1431-2.

17. Rajapakse JC, Giedd JN, Rumsey JM et al. Regional MRI 
measurements of the corpus callosum: a methodological and developmental study. Brain and dev 1996;18:379-88.

18. Junle Y, Youmin G, Yanjun G et al. A MRI quantitative study of corpus callosum in normal adults. J Med Colleges PLA 2008;23:346-51.

19. Witelson SF. The brain connection: the corpus callosum is larger in left-handers. Science 1985;229:665-8.

20. Erdogan $N$, Ülger $H$, Tuna I et al. A novel index to estimate the corpus callosum morphometry in adults: callosal/ supratentorialsupracallosal area ratio. Diagn Interv Radiol 2015;11:179.
21. Aydınlıoğlu A, Diyarbakırlı S, Yüceer $\mathrm{N}$ et al. The relationship of sex differences to the anatomy of the corpus callosum in the living human being. Turk Neurosurg 1996;6:1-2.

22. Eser O, Haktanır A, Boyacı MG et al. Korpus Kallozumun Morfometrik Ölçümleri. Türk Nöroşir Derg 2011;21:14-7.

23. Akin ME, Kurt AN. Corpus callosum morphology of healthy children: a structural magnetic resonance imaging study from Turkey. Eur J Anat 2020;24:467-73.

24. Achiron R, Lipitz S, Achiron A. Sex related differences in the development of the human fetal corpus callosum: in utero ultrasonographic study. Prenat Diagn 2001;21:116-20. 